\title{
Editorial: biodiversity of Caribbean coral reefs (with a focus on the Dutch Caribbean)
}

\author{
Bert W. Hoeksema ${ }^{1,2}$ • James D. Reimer ${ }^{3,4} \cdot$ Ronald Vonk ${ }^{1,5}$
}

Received: 15 November 2016 / Accepted: 13 January 2017 /Published online: 4 February 2017

(C) Senckenberg Gesellschaft für Naturforschung and Springer-Verlag Berlin Heidelberg 2017

\section{Biodiversity research on Caribbean coral reefs}

Coral reefs in the Atlantic have received less attention with regard to marine biodiversity research than those in the IndoPacific. In an overview of articles about corals or coral reefs in the journal Marine Biodiversity and its predecessor Senckenbergiana Maritima over the years 1969-2013, 35 papers concerned the Indo-Pacific and only 13 were about the Atlantic, a ratio of 2.7/1 (Hoeksema and Van der Meij 2013). Since that overview, 137 more papers on corals and coral reefs have been published in Marine Biodiversity. These include the present issue and articles that are still online-only. The updated ratio covering 1969 to the present is $134 / 51$, equaling $2.6 / 1$ in favor of the Indo-Pacific, which is slightly less than the previous ratio. In comparison, of 290 papers on corals and coral reefs published in the journal Coral Reefs during the years 2015-2016, 198 were about the Indo-Pacific and 92 about the Atlantic, which is a ratio of $2.15 / 1$. This ratio is smaller

Communicated by P. Martinez Arbizu

Bert W. Hoeksema

bert.hoeksema@naturalis.nl

1 Naturalis Biodiversity Center, P.O. Box 9517, 2300 RA Leiden, The Netherlands

2 Institute of Biology Leiden, Leiden University, P.O. Box 9505, 2300 RA Leiden, The Netherlands

3 Molecular Invertebrate Systematics and Ecology Laboratory, Graduate School of Engineering and Science, University of the Ryukyus, Senbaru 1, Nishihara, Okinawa 903-0213, Japan

4 Tropical Biosphere Research Center, University of the Ryukyus, Senbaru 1, Nishihara, Okinawa 903-0213, Japan

5 Institute for Biodiversity and Ecosystem Dynamics, University of Amsterdam, 1098 XH Amsterdam, The Netherlands than that found in Marine Biodiversity but it is still favoring the Indo-Pacific.

It has been known for a long time that the Atlantic has less coral reef surface area and fewer species than the Indo-Pacific (Ekman 1953; Briggs 1974; Veron 1995; Spalding et al. 2001). Worldwide, the highest concentrations of reef-dwelling species can be found in the Coral Triangle, which is located in the IndoAustralian Archipelago of the Central Indo-Pacific (Roberts et al. 2002; Hoeksema 2007; Bellwood and Meyer 2009). Other Indo-Pacific reef areas that have recently received attention regarding their high biodiversity and unique fauna elements are the South China Sea (Huang et al. 2015; Reimer et al. 2015), the West Indian Ocean (Obura 2016), and the Red Sea (DiBattista et al. 2016).

Marine biodiversity research by Naturalis Biodiversity Center (NBC) in Leiden had a major focus on the Coral Triangle for 30 years (1983-2012), which started with coral reef research during the ship-based Indonesian-Dutch Snellius II Expedition (1984) in collaboration with the Research Center for Oceanography of the Indonesian Institute of Sciences, RCO-LIPI (e.g., Best et al. 1989; Fransen 1989). Other NBC expeditions in Indonesia were land-based and operated from RCO-LIPI field stations and from dive resorts, including expeditions to Bali in 2001, East Kalimantan in 2004, Raja Ampat in 2007, and Ternate in 2009 (Hoeksema and Tuti 2001; Hoeksema 2004; Hoeksema and Van der Meij 2008, 2010).

The Caribbean is recognized as the most species-rich sea in the Atlantic regarding its coral reefs (Rocha et al. 2008; Miloslavich et al. 2010). It is connected to the Gulf of Mexico, with which it has many species in common (Felder and Camp 2009; Jaap 2015), although the northern part of the Gulf is considered a warm temperate ecoregion that is separate from the tropical Atlantic ecoregions of the Gulf and the Caribbean (Spalding et al. 2007; Fig. 1a). The Wider Caribbean or the Greater Caribbean includes the Caribbean, 
Fig. 1 a The Greater Caribbean with marine ecoregions after Burke and Maidens (2004) and Spalding et al. (2007). b The Dutch Caribbean composed of the Leeward Islands (Aruba, Curaçao, and Bonaire) in the Southern Caribbean and the Windward Islands (Saba, St. Eustatius, and St. Maarten) with Saba Bank in the Eastern Caribbean
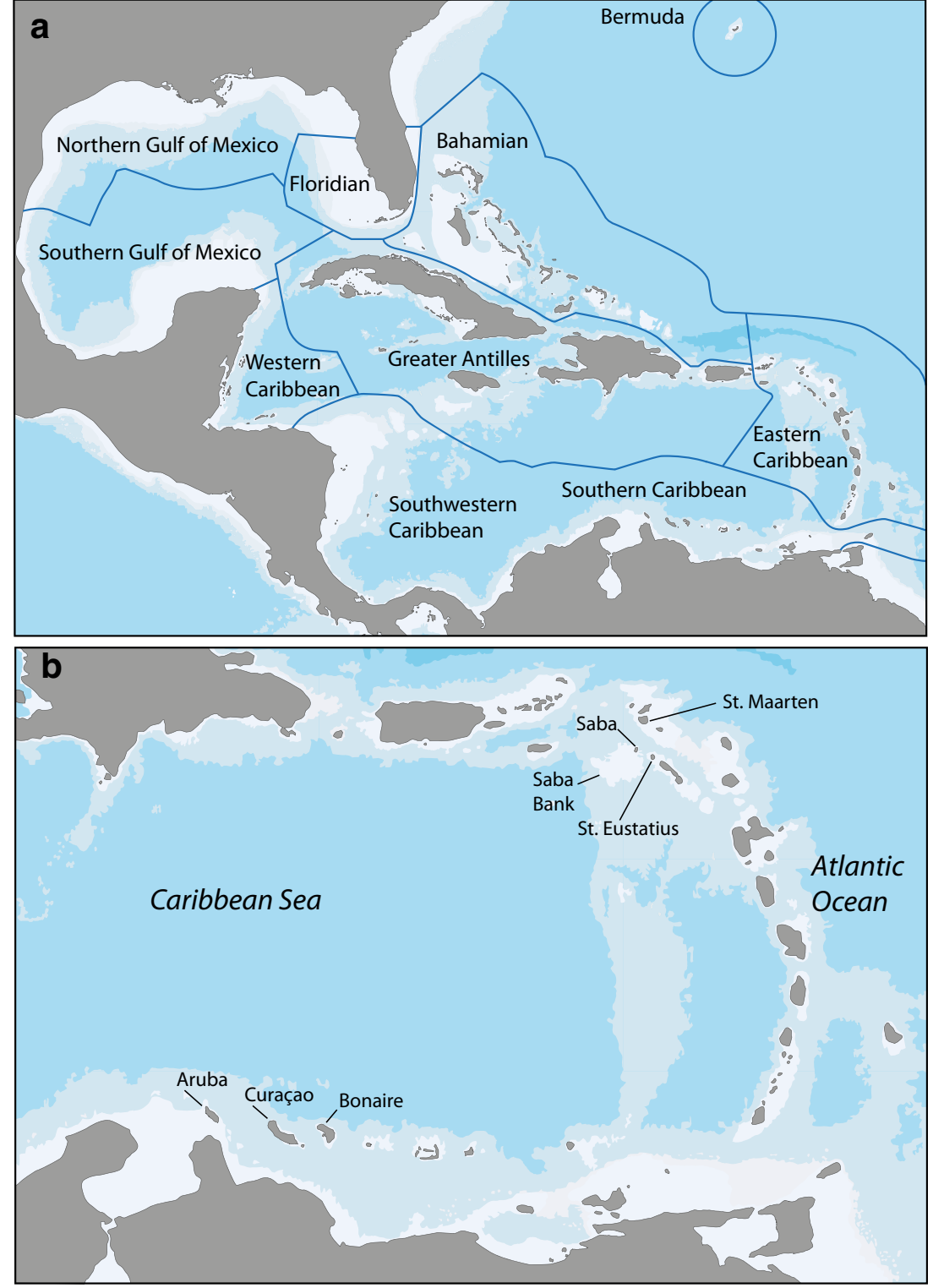

the Gulf of Mexico, and Bermuda in the northwestern Atlantic (Burke and Maidens 2004; Rocha et al. 2008; Wilkinson and Souter 2008; Robertson and Cramer 2014). Following Burke and Maidens (2004), we refer to this larger area simply as "the Caribbean" (Fig. 1a).

Although the Caribbean has less species than the Indo-Pacific, this does not imply that the marine fauna and flora of the Caribbean are sufficiently well known or that there is little need for additional biodiversity research on Caribbean reefs. The species compositions of both regions have traditionally been known to have little in common (Ekman 1953; Briggs 1974). Higher level taxa occurring in both oceans may show close affinities, although among scleractinian corals, this has appeared less so than originally thought (Fukami et al. 2004; Kitahara et al. 2016).
Anthropogenic introductions of Indo-Pacific species onto West Atlantic coral reefs have had various consequences for the reef faunas here. The mushroom coral family Fungiidae only naturally occurs in the Indo-Pacific (Hoeksema 1989; Gittenberger et al. 2011), but individuals of one species, Lobactis scutaria (Lamarck, 1801), with their Symbiodinium symbionts were brought to Jamaica in the 1960s, although no harmful effects have yet been reported (Bush et al. 2004; LaJeunesse et al. 2005). In contrast, the introduction of IndoPacific Tubastraea coral species and their range expansions in the West Atlantic since the 1930s has caused much concern due to their capacity to compete with endemic corals and to overgrow other organisms (Mantelatto and Creed 2015; Creed et al. 2016). The most notorious introductions are those of two species of lionfish, Pterois volitans (Linnaeus, 1758) and P. miles (Bennett, 1828), which have been spreading rapidly in the 
tropical West Atlantic since 1985 with increasing densities, while negatively impacting populations of local fish species. They have been reported from Rhode Island (USA) to the southeastern coast of Brazil (Dahl and Patterson 2014; Ferreira et al. 2015; Rocha et al. 2015; Chappell and Smith 2016; Hixon et al. 2016) down to mesophotic depths at $<300 \mathrm{~m}$ (Lesser and Slattery 2011; Albins and Hixon 2011; Nuttall et al. 2014; Aguilar-Perera et al. 2017). The latest aggressive intruder on Caribbean reefs is an undescribed species of xeniid octocoral in Venezuela, where it has been observed to overgrow and kill scleractinian corals since 2007 (Ruiz Allais et al. 2014). An earlier introduced Indo-Pacific octocoral species, Chromonephthea braziliensis van Ofwegen, 2005, was reported from Brazil, where it has been observed since around 1995, but no range expansion into the Caribbean has been reported (Ferreira 2003; Van Ofwegen 2005). Another octocoral species recently described as new from the western Atlantic, Stragulum bicolor van Ofwegen and Haddad, 2011, was presumably introduced recently because it has a restricted distribution off southern Brazil, while its closest relatives live in the Indo-Pacific (Van Ofwegen and Haddad 2011; Altvater and Coutinho 2015). A similar case is that of a new hydrozoan in the same area, which is of unknown origin but it has a sister species in Japan (Haddad et al. 2014). Finally, there are reports on a rapidly spreading invasive seagrass species originally from the Red Sea, Halophila stipulacea (Forsskål) Ascherson, 1867, competing with native seagrass species near coral reefs in various Caribbean localities (Becking et al. 2014; Willette et al. 2014; Van Tussenbroek et al. 2016; Van der Loos et al. 2017). Many marine exotic species in the Caribbean can easily be overlooked because they usually consist of invertebrates and algae that are not easily recognized (Debrot et al. 2011) and, therefore, they are usually discovered when they become invasive and their populations reach outbreak proportions.

Because of such harmful species introductions and possible local species extinctions on Caribbean coral reefs (e.g., Carpenter et al. 2008), there is a need for baseline surveys of local reef biota with specimen sampling and follow-up monitoring in order to be able to accurately notice when species arrive or disappear (Hoeksema et al. 2011; Rocha et al. 2014; Sampey and Marsh 2015; Ballard et al. 2016). Specimen collections can help to reveal what kind of species are easily misidentified or overlooked in reef surveys, usually those that are relatively small or deep-living (Hoeksema 2015). Caribbean coral reefs also deserve biodiversity research attention because not all of their species have been reported yet, and these species are likely to participate in hitherto unknown interspecific associations (e.g., Thomas and Klebba 2007; Snijders and Fransen 2010; Ivanenko et al. 2017; Montano et al. 2017b) or appear to have incomplete geographical and bathymetrical distribution range information involving new records for the Atlantic (e.g., Montano et al. 2017a; Van der Loos and Prud'homme van Reine 2017).
The present special issue of Marine Biodiversity on Caribbean coral reefs serves to add information on these points. The idea for this special issue began during the preparations of a marine biodiversity expedition to St. Eustatius in 2015 (Hoeksema 2016). In the Netherlands, recognition of the need for more biodiversity research in the Dutch Caribbean started to develop with the reorganization of the Kingdom in 2010, and NBC was assigned to play a role herein (RLG 2009). This role was facilitated by the establishment of the Caribbean Netherlands Science Institute (CNSI) on St. Eustatius in 2014. St. Eustatius is one of the islands of the former Netherlands Antilles, presently called the Dutch Caribbean (Figs. 1b and 2). Together with St. Maarten and Saba, it belongs to the windward islands in the eastern Caribbean, which also includes the submerged Saba Bank, while Aruba, Curaçao, and Bonaire belong to the Leeward Islands in the southern Caribbean (Fig. 1b). Within the Dutch Caribbean, Aruba, Curaçao, and the southern part of St. Maarten are separate states, whereas Bonaire, Saba, and St. Eustatius belong to the Caribbean Netherlands as municipalities (RLG 2009).

Much Caribbean research by NBC and other Dutch research institutes and universities has been performed on Curaçao, which received a research boost thanks to the establishment in 1955 of the Caribbean Marine Biological Institute (CARMABI), presently known as Caribbean Research and Management of Biodiversity. This resulted in many taxonomic reports on the fauna and flora of Curaçao, which were predominantly published in the journals Studies on the Fauna of Curaçao and other Caribbean Islands (1940-1980), Studies on the Flora of Curaçao and other Caribbean Islands (19561968), and Studies on the Natural History of the Caribbean Region (1992-2000). The papers published in these journals are available online (http://www.repository.naturalis.nl).

Taxonomists working at CARMABI or who received specimens from Curaçao dealt with crabs (Holthuis 1958), copepods (Stock et al. 1963; Stock 1973), fishes (Randall 1963), foraminiferans (Hofker 1964, 1971), algae (Vroman 1967; Van den Hoek 1978; Stegenga and Vroman 1987), tardigrades (Van der Land 1968), serpulid worms (Ten Hove 1970; Hoeksema et al. 2015; Hoeksema and Ten Hove 2017), opisthobranch molluscs (Marcus and du Bois-Reymond 1970), anthozoans (Den Hartog 1977, 1980), sponges (Van Soest 1980; De Weerdt et al. 1999), ascidians (Goodbody 1984), gastropod molluscs (De Jong and Coomans 1988), sea spiders (Stock 1989), sipunculans (Dean et al. 2007), and shrimps (Brinkmann and Fransen 2016; Hoeksema and Fransen 2017). In a preliminary census of animal species described as new from Dutch Caribbean specimen collections in the last 100 years, at least 310 were from Curaçao, as compared to 62 from Bonaire, 52 from Aruba, 10 from St. Maarten, four from St. Eustatius, four from Saba Bank, and three from Saba (Hoeksema and Bakker, in prep.). This confirms the traditional 


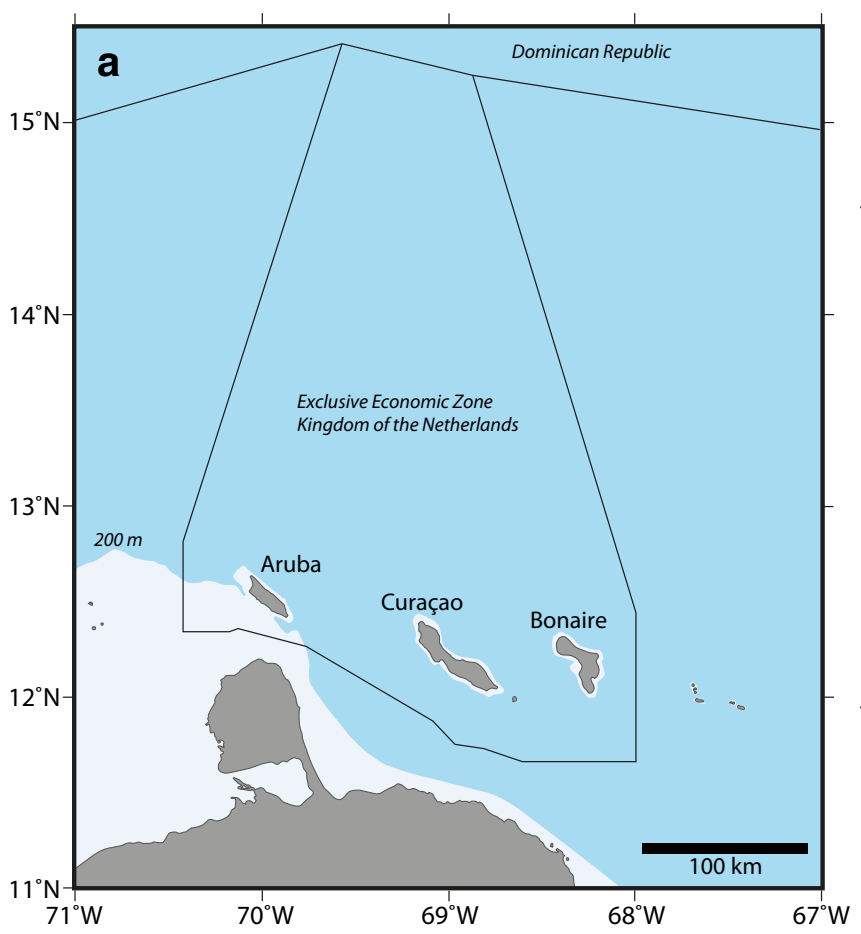

Fig. 2 Maps showing the Dutch Caribbean islands (former Netherlands Antilles) surrounded by $200-\mathrm{m}$ isobaths and Exclusive Economic Zone boundaries. a Leeward Islands (Aruba, Curaçao, and Bonaire), b Windward Islands (Saba, St. Eustatius, and the southern part of St.

importance of Curaçao and CARMABI for research on the taxonomy and biodiversity of Caribbean marine organisms.

In addition to professional scientists, students were also accommodated by CARMABI, which resulted in a considerable number of marine biodiversity publications based on graduate school research over five decades (e.g., Roos 1964, 1971; Bak 1975; Westinga and Hoetjes 1981; De Weerdt 1984; Van Duyl 1985; Fransen 1986; Vonk 1988, 1989, 1990; Meesters et al. 1991; Nagelkerken et al. 2001; Diekmann et al. 2002; Vermeij et al. 2003; Dorenbosch et al. 2004; Frade et al. 2008; Reijnen et al. 2010; Snijders and Fransen 2010; Van der Meij 2014; Wolf et al. 2014; De Bakker et al. 2016; Van Tienderen and Van der Meij 2016; Böhm and Hoeksema 2017; Potkamp et al. 2017). In addition, research vessels of the Royal Netherlands Navy performed scientific surveys in the Caribbean and other parts of the Atlantic, such as an expedition to Saba Bank in 1972 (Van der Land 1977; Hoeksema et al. 2011).

With the operation of the manned submersible Curasub for scientific purposes since 2010, mesophotic coral reefs and deeper environments of Curaçao and other Caribbean areas have become accessible for surveys to depths of ca. $300 \mathrm{~m}$. This has already led to various new species discoveries (Van Tassell et al. 2012; Baldwin and Johnson 2014; Baldwin and Robertson 2013, 2014, 2015; Harasewych 2014; Van Soest et al. 2014; Harasewych and Tëmkin 2015; Baldwin et al. 2016; Tornabene et al. 2016a, b), new distribution records

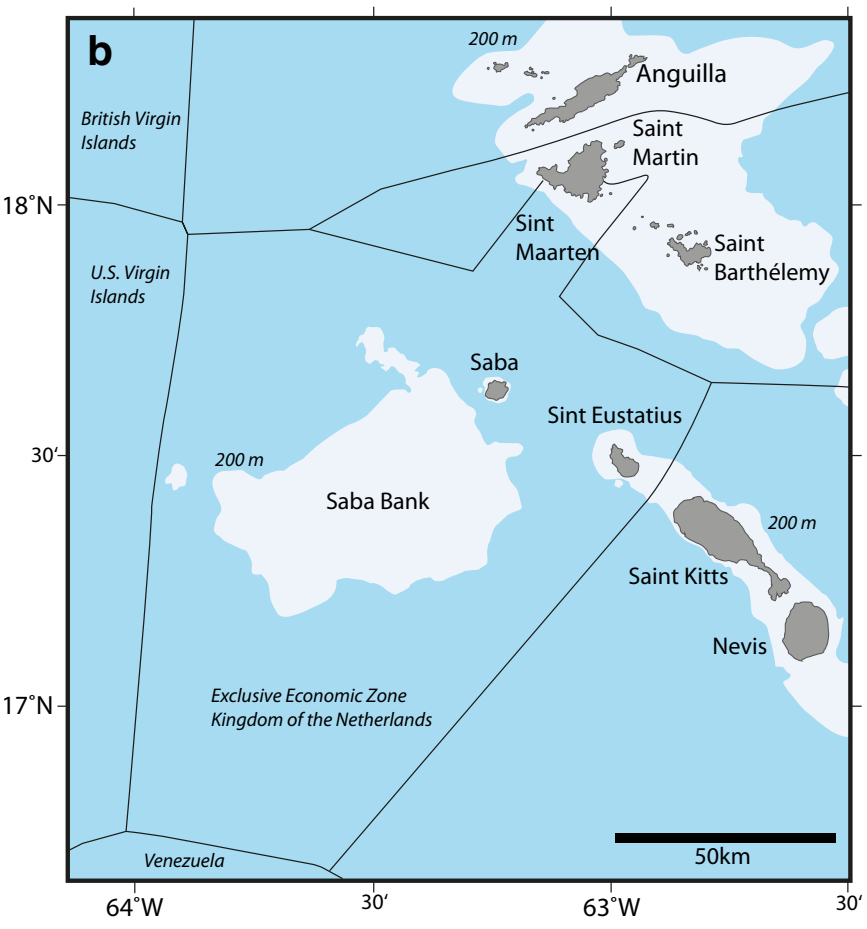

Maarten) with the submerged Saba Bank. Sources: https://www. defensie.nl/english/topics/hydrography/contents/maritime-zones-andboundaries; Royal Netherlands Navy maps 2020, 2023, 2110, 2211, 2212, 2213, 2716

(Pawson and Pawson 2013; Fransen 2014; Lemaitre and Tavares 2015), as well as new depth records for some species (Van der Meij et al. 2015; Tornabene et al. 2016c; Hoeksema et al. 2017a).

The marine biodiversity expedition to St. Eustatius in 2015 and some recent malacological surveys have resulted in various new discoveries for the eastern Caribbean. These concerned new species (e.g., Montano et al. 2017b; Vonk and Lau 2017), new species records for the Atlantic (Montano et al. 2017a; Van der Loos and Prud'homme van Reine 2017), new host records in interspecific associations (GarcíaHernández et al. 2016; Hoeksema et al. 2017b; Ivanenko et al. 2017; Montano et al. 2017a, b), new records on interspecific competition (García-Hernández et al. 2017), and new records concerning the island's flora and fauna (Hewitt 2015; Hewitt et al. 2016; Davies and Piontek 2017; Van der Loos et al. 2017). These recently published reports show that much can still be discovered regarding the marine fauna and flora of Caribbean coral reefs. Many of these reports from the Dutch Caribbean are published in the present issue of Marine Biodiversity, along with papers based on research in other Caribbean regions, such as the Florida Keys (Adam et al. 2017), the southern Gulf of Mexico (Aguilar-Perera and Hernández-Landa 2017; Aguilar-Perera et al. 2017; Stampar et al. 2017), Puerto Rico (Galindo Estronza et al. 2017; Hammerman and García-Hernández 2017), and Cuba (RuizAbierno and Armenteros 2017). 


\section{Caribbean biodiversity research in Marine Biodiversity}

The number of journals dealing predominantly with the marine biodiversity of Caribbean coral reefs has declined in recent years. The aforementioned Dutch journals focusing on the natural history of the Caribbean islands have ceased to exist. Traditionally, the Bulletin of Marine Science has published many papers on the Caribbean and the Gulf of Mexico, as between 1951 and 1965 it was named the Bulletin of Marine Science of the Gulf and Caribbean, but since 1965, it has no longer had a strict focus on the tropical western Atlantic. Another relevant regional journal is the Caribbean Journal of Science, which has been published since 1961. Obviously, the journal Coral Reefs (since 1982) includes research focused on coral reefs, including those in the Caribbean (see above).

Marine Biodiversity (since 2009) is not strictly related to tropical ecosystems, but in the scope of the present special issue, it is interesting to see what kind of attention has been given to coral reef biodiversity (Hoeksema and Van der Meij 2013), and, in particular, which Caribbean marine ecoregions and taxa have been covered and investigated thus far. Such information may serve as a basis to generate ideas for future

Table 1 Representation of Caribbean marine ecoregions by numbers of articles dealing with corals or reefs published in the journal Marine Biodiversity and its predecessor Senckenbergiana Maritima (1969$2016+2017$ present issue $=$ total $)$. Some articles cover more than one ecoregion

Eastern Caribbean $(3+9=12)$ : Kleemann $(1986,1990)$, Alvarado (2011), Davies and Piontek (2017), García-Hernández et al. (2017), Hoeksema et al. (2017b), Ivanenko et al. (2017), Montano et al. (2017a, b), Van der Loos and Prud'homme van Reine (2017), Van der Loos et al. (2017), Vonk and Lau (2017)

Greater Antilles $(5+3=8)$ : Alvarado (2011), Hochberg et al. (2014), Reuscher and Shirley (2014), Corgosinho et al. (2016), Lucas and Weil (2016), Galindo Estronza et al. (2017), Hammerman and García-Hernández (2017), Ruiz-Abierno and Armenteros (2017)

Southern Caribbean $(4+4=8)$ : Alvarado (2011), Davies et al. (2013), Santodomingo et al. (2013), Bernal et al. (2016), Böhm and Hoeksema (2017), Hoeksema and Ten Hove (2017), Hoeksema et al. (2017a), Potkamp et al. (2017)

Southern Gulf of Mexico $(1+3=4)$ : Reuscher and Shirley (2014), Aguilar-Perera and Hernández-Landa (2017), Aguilar-Perera et al. (2017), Stampar et al. (2017)

Southwestern Caribbean $(4+0=4)$ : Kleemann (1990), Alvarado (2011), Santodomingo et al. (2013), Guerrero-Kommritz and Camelo-Guarin (2016)

Floridian $(3+0=3)$ : Reuscher and Shirley (2014), Netchy et al. (2016), Adam et al. (2017)

Northern Gulf of Mexico $(2+0=2)$ : Davies et al. (2013), Reuscher and Shirley (2014)

Western Caribbean $(2+0=2)$ : Alvarado (2011), Bernal et al. (2016)

Bahamian $(1+0=1)$ : Porto-Hannes and Lasker (2013)

Bermuda (0) research. Most publications on the biodiversity of Caribbean corals or coral reefs in this journal were published from 2016 onwards, and the majority concern the Eastern Caribbean, whereas the Greater Antilles and the Southern Caribbean share second place (Table 1). It is not surprising that cnidarians (including scleractinians) rank highest according to the number of publications, which is more than double the number of the next closest taxon (Table 2).

The editors hope that this special issue will encourage authors to publish more papers on the Caribbean in the journal Marine Biodiversity. For many taxa, there are no good overview studies available that show the distribution patterns of species richness in the Caribbean or the West Atlantic as a whole (see, for example, Cairns 2007; Miloslavich et al. 2010; Petuch 2013), whereas many such studies are available for the much larger Indo-Pacific (see the review by Hoeksema 2007). As Brazilian reef biota (including invasive species and diseases) in eight marine ecoregions show both similarities and differences with Caribbean reefs (e.g. Rocha et al. 2008; Nunes et al. 2011), with reef corals found to $27^{\circ} \mathrm{S}$ latitude (Capel et al. 2012) and reef fishes to $28^{\circ} \mathrm{S}$ (Floeter et al. 2001), it would also be interesting to include more papers on coral reefs from Brazil in order to facilitate comparisons between the biota of both areas and to study their connectivity

Table 2 Representation of Caribbean taxa and other species groups by numbers of articles dealing with corals or reefs published in the journal Marine Biodiversity and its predecessor Senckenbergiana Maritima (1969-2017 present issue). Some articles cover more than one species group

Cnidarians (14): Davies et al. (2013), Porto-Hannes and Lasker (2013), Santodomingo et al. (2013), Lucas and Weil (2016), García-Hernández et al. (2017), Hammerman and García-Hernández (2017), Hoeksema and Ten Hove (2017), Hoeksema et al. (2017a, b), Ivanenko et al. (2017), Montano et al. (2017a, b), Potkamp et al. (2017), Stampar et al. (2017)

Fishes (6): Adam et al. (2017), Aguilar-Perera and Hernández-Landa (2017), Aguilar-Perera et al. (2017), Böhm and Hoeksema (2017), Davies and Piontek (2017), Hoeksema et al. (2017a)

Crustaceans (5): Corgosinho et al. (2016), Galindo Estronza et al. (2017), Hoeksema et al. (2017b), Ivanenko et al. (2017), Vonk and Lau (2017)

Mollusca (4): Kleemann (1986, 1990), Guerrero-Kommritz and Camelo-Guarin (2016), Potkamp et al. (2017)

Polychaetes (3): Reuscher and Shirley (2014), Hoeksema and Ten Hove (2017), Hoeksema et al. (2017b)

Reef fauna assemblages (3): Netchy et al. (2016), Hoeksema et al. (2017b), Ruiz-Abierno and Armenteros (2017)

Algae (2): Van der Loos and Prud'homme van Reine (2017), Van der Loos et al. (2017)

Sponges (2): García-Hernández et al. (2017), Hammerman and García-Hernández (2017)

Fish parasites (1): Bernal et al. (2016)

Echinoderms (1): Alvarado (2011)

Gastrotricha (1): Hochberg et al. (2014) 
(see, for example, Dias and Gondim 2016; Mizrahi et al. 2016; Pinto et al. 2016; Santos et al. 2016; Soares et al. 2016a, b).

Acknowledgments We are grateful to the editor of Marine Biodiversity and the publisher for allowing us to compile contributions for this special issue on Caribbean coral reefs. We also thank all the contributors. This special issue would not have been possible without the support to marine biodiversity research given by the directors and staffs of the Caribbean Marine Biological Institute (CARMABI) and Substation Curaçao at Curaçao, and the Caribbean Netherlands Science Institute (CNSI) at St. Eustatius.

\section{References}

Adam TC, Kelley M, Ruttenberg BI, Burkepile DE (2017) Groups of roving midnight parrotfish (Scarus coelestinus) prey on sergeant major damselfish (Abudefduf saxatilis) nests. Mar Biodivers 47 (this issue). doi:10.1007/s12526-016-0475-4

Aguilar-Perera A, Hernández-Landa RC (2017) The rainbow parrotfish (Scarus guacamaia) does not depend on mangroves as nursery habitats in the Parque Nacional Arrecife Alacranes, Southern Gulf of Mexico. Mar Biodivers 47 (this issue). doi:10.1007/s12526-0160491-4

Aguilar-Perera A, Quijano-Puerto L, Hernández-Landa RC (2017) Lionfish invaded the mesophotic coral ecosystem of the Parque Nacional Arrecife Alacranes, Southern Gulf of Mexico. Mar Biodivers 47 (this issue). doi:10.1007/s12526-016-0536-8

Albins MA, Hixon MA (2011) Worst case scenario: potential long-term effects of invasive predatory lionfish (Pterois volitans) on Atlantic and Caribbean coral-reef communities. Environ Biol Fish 96:11511157. doi:10.1007/s10641-011-9795-1

Altvater L, Coutinho R (2015) Colonisation, competitive ability and influence of Stragulum bicolor Van Ofwegen and Haddad, 2011 (Cnidaria, Anthozoa) on the fouling community in Paranaguá Bay, Southern Brazil. J Exp Mar Biol Ecol 462:55-61. doi:10.1016/j. jembe.2014.10.007

Alvarado JJ (2011) Echinoderm diversity in the Caribbean Sea. Mar Biodivers 41:261-285. doi:10.1007/s12526-010-0053-0

Bak RPM (1975) Ecological aspects of the distribution of reef corals in the Netherlands Antilles. Bijdr Dierk 45:181-190

Baldwin CC, Johnson GD (2014) Connectivity across the Caribbean Sea: DNA barcoding and morphology unite an enigmatic fish larva from the Florida Straits with a new species of sea bass from deep reefs off Curaçao. PLoS One 9(5):e97661. doi:10.1371/journal.pone. 0097661

Baldwin CC, Robertson DR (2013) A new Haptoclinus blenny (Teleostei, Labrisomidae) from deep reefs off Curaçao, southern Caribbean, with comments on relationships of the genus. ZooKeys 306:71-81. doi:10.3897/zookeys.306.5198

Baldwin CC, Robertson DR (2014) A new Liopropoma sea bass (Serranidae, Epinephelinae, Liopropomini) from deep reefs off Curaçao, southern Caribbean, with comments on depth distributions of western Atlantic liopropomins. ZooKeys 409:71-92. doi:10. 3897/zookeys.409.7249

Baldwin CC, Robertson DR (2015) A new, mesophotic Coryphopterus goby (Teleostei, Gobiidae) from the southern Caribbean, with comments on relationships and depth distributions within the genus. ZooKeys 513:123-142. doi:10.3897/zookeys.513.9998

Baldwin CC, Robertson DR, Nonaka A, Tornabene L (2016) Two new deep-reef basslets (Teleostei, Grammatidae, Lipogramma), with comments on the eco-evolutionary relationships of the genus. ZooKeys 638:45-82. doi:10.3897/zookeys.638.10455
Ballard HL, Robinson LD, Young AN, Pauly GB, Higgins LM, Johnson RF, Tweddle JC (2016) Contributions to conservation outcomes by natural history museum-led citizen science: examining evidence and next steps. Biol Conserv. doi:10.1016/j.biocon.2016.08.040

Becking LE, Van Bussel TCJM, Debrot AO, Christianen MJA (2014) First record of a Caribbean green turtle (Chelonia mydas) grazing on invasive seagrass (Halophila stipulacea). Caribb J Sci 48:162-163

Bellwood DR, Meyer CP (2009) Searching for heat in a marine biodiversity hotspot. J Biogeogr 36:569-576. doi:10.1111/j.1365-2699. 2008.02029.x

Bernal MA, Floeter SR, Gaither MR, Longo GO, Morais R, Ferreira CE, Vermeij MJA, Rocha LA (2016) High prevalence of dermal parasites among coral reef fishes of Curaçao. Mar Biodivers 46:67-74. doi:10.1007/s12526-015-0322-z

Best MB, Hoeksema BW, Moka W, Moll H, Suharsono, Sutarna IN (1989) Recent scleractinian coral species collected during the Snellius-II Expedition in eastern Indonesia. Neth J Sea Res 23: 107-115. doi:10.1016/0077-7579(89)90005-7

Böhm T, Hoeksema BW (2017) Habitat selection of the coral-dwelling spinyhead blenny, Acanthemblemaria spinosa, at Curaçao, Dutch Caribbean. Mar Biodivers 47 (this issue). doi:10.1007/s12526016-0543-9

Briggs JC (1974) Marine zoogeography. McGraw-Hill, New York

Brinkmann BW, Fransen CHJM (2016) Identification of a new stony coral host for the anemone shrimp Periclimenes rathbunae Schmitt, 1924 with notes on the host-use pattern. Contrib Zool 85: 437-456

Burke L, Maidens J (2004) Reefs at risk in the Caribbean. World Resources Institute (WRI), Washington, DC

Bush SL, Precht WF, Woodley JD, Bruno JF (2004) Indo-Pacific mushroom corals found on Jamaican reefs. Coral Reefs 23:234. doi:10. 1007/s00338-004-0372-3

Cairns SD (2007) Deep-water corals: an overview with special reference to diversity and distribution of deep-water scleractinian corals. Bull Mar Sci 81:311-322

Capel C, Segal B, Bertuol P, Lindner A (2012) Corallith beds at the edge of the tropical South Atlantic. Coral Reefs 31:75. doi:10.1007/ s00338-011-0818-3

Carpenter KE, Abrar M, Aeby G, Aronson RB, Banks S, Bruckner A et al (2008) One-third of reef-building corals face elevated extinction risk from climate change and local impacts. Science 321:560-563. doi: 10.1126/science. 1159196

Chappell BF, Smith KG (2016) Patterns of predation of native reef fish by invasive Indo-Pacific lionfish in the western Atlantic: evidence of selectivity by a generalist predator. Global Ecol Conserv 8:18-23. doi:10.1016/j.gecco.2016.08.002

Corgosinho PH, Schizas NV, Lozano MA (2016) A new species of Atergopedia (Copepoda: Harpacticoida: Novocriniidae) from a Caribbean mesophotic reef. Mar Biodivers 46:841-852. doi:10. 1007/s12526-016-0446-9

Creed JC, Fenner D, Sammarco P, Cairns S, Capel K, Junqueira AOR, Cruz I, Miranda RJ, Carlos-Junior L, Mantelatto MC, OigmanPszczol S (2016) The invasion of the azooxanthellate coral Tubastraea (Scleractinia: Dendrophylliidae) throughout the world: history, pathways and vectors. Biol Invasions 19:283-305. doi:10. 1007/s10530-016-1279-y

Dahl KA, Patterson WF (2014) Habitat-specific density and diet of rapidly expanding invasive red lionfish, Pterois volitans, populations in the northern Gulf of Mexico. PLoS One 9:e105852. doi:10.1371/ journal.pone. 0105852

Davies MR, Piontek S (2017) The marine fishes of St. Eustatius, Dutch Caribbean. Mar Biodivers 47 (this issue). doi:10.1007/s12526-0160575-1

Davies SW, Rahman M, Meyer E, Green EA, Buschiazzo E, Medina M, Matz MV (2013) Novel polymorphic microsatellite markers for population genetics of the endangered Caribbean star coral, 
Montastraea faveolata. Mar Biodivers 43:167-172. doi:10.1007/ s12526-012-0133-4

De Bakker DM, Meesters EH, Bak RPM, Nieuwland G, Van Duyl FC (2016) Long-term shifts in coral communities on shallow to deep reef slopes of Curaçao and Bonaire: are there any winners? Front Mar Sci 3:247. doi:10.3389/fmars.2016.00247

De Jong KM, Coomans HE (1988) Marine Gastropods from Curaçao, Aruba and Bonaire. Stud Fauna Curaçao Caribb Is 69:1-261

De Weerdt WH (1984) Taxonomic characters in Caribbean Millepora species (Hydrozoa, Coelenterata). Bijdr Dierk 54:243-255

De Weerdt WH, De Kluijver MJ, Gomez R (1999) Haliclona (Halichoclona) vansoesti n. sp., a new chalinid sponge species (Porifera, Demospongiae, Haplosclerida) from the Caribbean. Beaufortia 49:47-54

Dean HK, Hernandez-Avila I, Cutler EB (2007) Sipunculans of the Caribbean coast of Venezuela and Curaçao. Zootaxa 1431:45-54

Debrot AE, Van Buurt G, Vermeij MJA (2011) Preliminary overview of exotic and invasive marine species in the Dutch Caribbean. Report C188/11. IMARES Wageningen UR

Den Hartog JC (1977) Descriptions of two new Ceriantharia from the Caribbean region, Pachycerianthus curacaoensis n. sp. and Arachnanthus nocturnus n. sp., with a discussion of the cnidom and of the classification of the Ceriantharia. Zool Meded 51:211-242

Den Hartog JC (1980) Caribbean shallow water Corallimorpharia. Zool Verh $176: 1-83$

Dias TLP, Gondim AI (2016) Bleaching in scleractinians, hydrocorals, and octocorals during thermal stress in a northeastern Brazilian reef. Mar Biodivers 46:303-307. doi:10.1007/s12526-015-0342-8

DiBattista JD, Roberts MB, Bouwmeester J, Bowen BW, Coker DJ, Lozano-Cortés DF et al (2016) A review of contemporary patterns of endemism for shallow water reef fauna in the Red Sea. J Biogeogr 43:423-439. doi:10.1111/jbi.12649

Diekmann OE, Bak RPM, Tonk L, Stam WT, Olsen JL (2002) No habitat correlation of zooxanthellae in the coral genus Madracis on a Curaçao reef. Mar Ecol Prog Ser 227:221-232. doi:10.3354/ meps 227221

Dorenbosch M, Van Riel MC, Nagelkerken I, Van der Velde G (2004) The relationship of reef fish densities to the proximity of mangrove and seagrass nurseries. Estuar Coast Shelf Sci 60:37-48. doi:10. 1016/j.ecss.2003.11.018

Ekman S (1953) Zoogeography of the sea. Sidgwick and Jackson, London

Felder DL, Camp DK (2009) Gulf of Mexico. Origins, waters, and biota. Vol. 1. Biodiversity. Texas A\&M University Press, College Station

Ferreira CEL (2003) Non-indigenous corals at marginal sites. Coral Reefs 22:498. doi:10.1007/s00338-003-0328-Z

Ferreira CEL, Luiz OJ, Floeter SR, Lucena MB, Barbosa MC, Rocha CR, Rocha LA (2015) First record of invasive lionfish (Pterois volitans) for the Brazilian coast. PLoS One 10:e123002. doi:10.1371/ journal.pone. 0123002

Floeter SR, Guimaraes RZ, Rocha LA, Ferreira CEL, Rangel CA, Gasparini JL (2001) Geographic variation in reef-fish assemblages along the Brazilian coast. Global Ecol Biogeogr 10:423-431. doi: 10.1046/j.1466-822X.2001.00245.X

Frade PR, De Jongh F, Vermeulen F, Van Bleijswijk J, Bak RPM (2008) Variation in symbiont distribution between closely related coral species over large depth ranges. Mol Ecol 17:691-703. doi:10.1111/j. 1365-294X.2007.03612.x

Fransen CHJM (1986) Caribbean Bryozoa: Anasca and Ascophora imperfecta of the inner bays of Curacao and Bonaire. Stud Fauna Curaçao Caribb Is 68:1-102

Fransen CHJM (1989) Notes on caridean shrimps collected during the Snellius-II expedition. I. Associates of Anthozoa. Neth J Sea Res 23: 131-147. doi:10.1016/0077-7579(89)90008-2
Fransen CHJM (2014) A second discovery of Diapontonia maranulus Bruce, 1986 (Crustacea: Decapoda: Palaemonidae) in the Caribbean. Zootaxa 3881:591-596. doi:10.11646/zootaxa.3881.6.8

Fukami H, Budd AF, Paulay G, Solé-Cava A, Chen CA, Iwao K, Knowlton N (2004) Conventional taxonomy obscures deep divergence between Pacific and Atlantic corals. Nature 427:832-835. doi:10.1038/nature02339

Galindo Estronza AM, Alfaro M, Schizas NV (2017) Morphological and genetic species diversity in ostracods (Crustacea: Oligostraca) from Caribbean reefs. Mar Biodivers 47 (this issue). doi:10.1007/s12526016-0525-y

García-Hernández JE, Reimer JD, Hoeksema BW (2016) Sponges hosting the Zoantharia-associated crab Platypodiella spectabilis at St. Eustatius, Dutch Caribbean. Coral Reefs 35:209. doi:10.1007/ s00338-015-1364-1

García-Hernández JE, Van Moorsel GWNM, Hoeksema BW (2017) Lettuce corals overgrowing tube sponges at St. Eustatius, Dutch Caribbean. Mar Biodivers 47 (this issue). doi:10.1007/s12526016-0467-4

Gittenberger A, Reijnen BT, Hoeksema BW (2011) A molecularly based phylogeny reconstruction of mushroom corals (Scleractinia: Fungiidae) with taxonomic consequences and evolutionary implications for life history traits. Contrib Zool 80:107-132

Goodbody I (1984) The ascidian fauna of two contrasting lagoons in the Netherlands Antilles: Piscadera Baai, Curaçao, and the Lac of Bonaire. Stud Fauna Curaçao Caribb Is 67:21-49

Guerrero-Kommritz J, Camelo-Guarin S (2016) Two new octopod species (Mollusca: Cephalopoda) from the southern Caribbean. Mar Biodivers 46:589-602. doi:10.1007/s12526-015-0406-9

Haddad MA, Bettim AL, Miglietta MP (2014) Podocoryna loyola, n. sp (Hydrozoa, Hydractiniidae): a probably introduced species on artificial substrate from southern Brazil. Zootaxa 3796:494-506. doi: 10.11646/zootaxa.3796.3.5

Hammerman NM, García-Hernández JE (2017) The sponge Xestospongia muta offers shelter to the stony coral Madracis auretenra (Northwest Puerto Rico). Mar Biodivers 47 (this issue). doi:10.1007/s12526-016-0574-2

Harasewych MG (2014) Attenuiconus marileeae, a new species of cone (Gastropoda: Conidae: Puncticulinae) from Curaçao. Nautilus 128: $55-58$

Harasewych MG, Tëmkin I (2015) The Miocene genus Mantellina (Bivalvia: Limidae) discovered living on the deep reefs off Curaçao, with the description of a new species. J Moll Stud 81: 442-454. doi:10.1093/mollus/eyv021

Hewitt SJ (2015) Checklist of marine molluses from the island of Sint Eustatius, Leeward Islands, West Indies. Basteria 79:39-47

Hewitt SJ, van Leeuwen S, Schrieken N (2016) New information on Pleurolucina hendersoni (Britton, 1972) (Mollusca: Bivalvia, Lucinidae) from the Dutch island of St. Eustatius, West Indies. Basteria 80:157-160

Hixon MA, Green SJ, Albins MA, Akins JL, Morris JA Jr (2016) Lionfish: a major marine invasion. Mar Ecol Prog Ser 558:161165. doi:10.3354/meps 11909

Hochberg R, Atherton S, Kieneke A (2014) Marine Gastrotricha of Little Cayman Island with the description of one new species and an initial assessment of meiofaunal diversity. Mar Biodivers 44:89-113. doi: 10.1007/s12526-013-0186-z

Hoeksema BW (1989) Taxonomy, phylogeny and biogeography of mushroom corals (Scleractinia: Fungiidae). Zool Verh 254:1-295

Hoeksema BW (2004) Marine biodiversity of the coastal area of the Berau region, East Kalimantan, Indonesia. Progress report East Kalimantan Program, pilot phase (October 2003), Naturalis, Leiden

Hoeksema BW (2007) Delineation of the Indo-Malayan centre of maximum marine biodiversity: the Coral Triangle. In: Renema W (ed) Biogeography, time, and place: distributions, 
barriers, and islands. Springer, Dordrecht, pp 117-178. doi: 10.1007/978-1-4020-6374-9_5

Hoeksema BW (2015) Latitudinal species diversity gradient of mushroom corals off eastern Australia: a baseline from the 1970s. Estuar Coast Shelf Sci 165:190-198. doi:10.1016/j. ecss.2015.05.015

Hoeksema BW (2016) Marine biodiversity survey of St. Eustatius, Dutch Caribbean, 2015. Naturalis Biodiversity Center, Leiden, and ANEMOON Foundation, Bennebroek

Hoeksema BW, Fransen CHJM (2017) Host switch by the Caribbean anemone shrimp Periclimenes rathbunae in Curaçao. Coral Reefs. doi:10.1007/s00338-017-1541-5

Hoeksema BW, Ten Hove HA (2017) The invasive sun coral Tubastraea coccinea hosting a native Christmas tree worm at Curaçao, Dutch Caribbean. Mar Biodivers 47 (this issue). doi:10.1007/s12526-016-0472-7

Hoeksema BW, Tuti Y (2001) Marine biodiversity of Lombok Strait, Bali: preliminary research report. NNM Naturalis, Leiden

Hoeksema BW, Van der Meij SET (2008) Cryptic marine biota of the Raja Ampat Islands group. Naturalis, Leiden

Hoeksema BW, Van der Meij SET (2010) Crossing marine lines at Ternate: capacity building of junior scientist in Indonesia for marine biodiversity assessments. Naturalis, Leiden

Hoeksema BW, Van der Meij SET (2013) Editorial: corals, reefs and marine biodiversity. Mar Biodivers 43:1-6. doi:10.1007/s12526013-0145-8

Hoeksema BW, Van der Land J, Van der Meij SET, Van Ofwegen LP, Reijnen BT, Van Soest RWM, De Voogd NJ (2011) Unforeseen importance of historical collections as baselines to determine biotic change of coral reefs: the Saba Bank case. Mar Ecol 32:135-141. doi:10.1111/j.1439-0485.2011.00434.x

Hoeksema BW, Lau YW, Ten Hove HA (2015) Octocorals as secondary hosts for Christmas tree worms off Curaçao. Bull Mar Sci 91:489 490. doi:10.5343/bms.2015.1049

Hoeksema BW, Bongaerts P, Baldwin CC (2017a) High coral cover at lower mesophotic depths: a dense Agaricia community at the leeward side of Curaçao, Dutch Caribbean. Mar Biodivers 47 (this issue). doi:10.1007/s12526-015-0431-8

Hoeksema BW, Van Beusekom M, Ten Hove HA, Ivanenko VN, Van der Meij SET, Van Moorsel GWNM (2017b) Helioseris cucullata as a host coral at St. Eustatius, Dutch Caribbean. Mar Biodivers 47 (this issue). doi:10.1007/s12526-016-0599-6

Hofker J (1964) Foraminifera from the tidal zone in the Netherlands Antilles and other West Indian islands. Stud Fauna Curaçao Caribb Is 21:1-119

Hofker J (1971) The foraminifera of Piscadera Bay, Curaçao. Stud Fauna Curaçao Caribb Is 35:1-62

Holthuis LB (1958) West Indian crabs of the genus Calappa, with a description of three new species. Stud Fauna Curaçao Caribb Is 8: 146-186

Huang D, Licuanan WY, Hoeksema BW, Chen CA, Ang PO, Huang H, Lane DJW, Vo ST, Waheed Z, Affendi YA, Yeemin T, Chou LM (2015) Extraordinary diversity of reef corals in the South China Sea. Mar Biodivers 45:157-168. doi:10.1007/s12526-014-0236-1

Ivanenko VN, Nikitin MA, Hoeksema BW (2017) Multiple purple spots in the Caribbean sea fan Gorgonia ventalina caused by parasitic copepods at St. Eustatius, Dutch Caribbean. Mar Biodivers 47 (this issue). doi:10.1007/s12526-015-0428-3

Jaap WC (2015) Stony coral (Milleporidae and Scleractinia) communities in the eastern Gulf of Mexico: a synopsis with insights from the Hourglass collections. Bull Mar Sci 91:207-253. doi:10.5343/bms. 2014.1049

Kitahara MV, Fukami H, Benzoni F, Huang D (2016) The new systematics of Scleractinia: integrating molecular and morphological evidence. In: Goffredo S, Dubinsky Z (eds) The Cnidaria, past, present and future. Springer, Switzerland, pp 41-59. doi:10.1007/978-3319-31305-4 4

Kleemann KH (1986) Das bohren and wachstum von Gregariella (Bivalvia: Mytilacea) aus der Karibik und dem Ost-Pazifik. Senckenberg Marit 18:187-209

Kleemann K (1990) Boring and growth in chemically boring bivalves from the Caribbean, Eastern Pacific and Australia's Great Barrier Reef. Senckenberg Marit 21:101-154

LaJeunesse TC, Lee S, Bush S, Bruno JF (2005) Persistence of nonCaribbean algal symbionts in Indo-Pacific mushroom corals released to Jamaica 35 years ago. Coral Reefs 24:157-159. doi:10. 1007/s00338-004-0436-4

Lemaitre R, Tavares M (2015) New taxonomic and distributional information on hermit crabs (Crustacea: Anomura: Paguroidea) from the Gulf of Mexico, Caribbean Sea, and Atlantic coast of South America. Zootaxa 3994:451-506. doi:10.11646/zootaxa.3994.4.1

Lesser MP, Slattery M (2011) Phase shift to algal dominated communities at mesophotic depths associated with lionfish (Pterois volitans) invasion on a Bahamian coral reef. Biol Invasions 13:1855-1868. doi: 10.1007/s10530-011-0005-Z

Lucas MQ, Weil E (2016) Recent recovery in Acropora cervicornis and abundance of $A$. prolifera off La Parguera, Puerto Rico. Mar Biodivers 46:531-532. doi:10.1007/s12526-015-0399-4

Mantelatto MC, Creed JC (2015) Non-indigenous sun corals invade mussel beds in Brazil. Mar Biodivers 45:605-606. doi:10.1007/s12526014-0282-8

Marcus E, du Bois-Reymond ME (1970) Opisthobranchs from Curaçao and faunistically related regions. Stud Fauna Curaçao Caribb Is 33: $1-129$

Meesters E, Knijn R, Willemsen P, Pennartz R, Roebers G, Van Soest RWM (1991) Sub-rubble communities of Curaçao and Bonaire coral reefs. Coral Reefs 10:189-197. doi:10.1007/BF00336773

Miloslavich P, Díaz JM, Klein E, Alvarado JJ, Díaz C, Gobin J et al (2010) Marine biodiversity in the Caribbean: regional estimates and distribution patterns. PLoS One 5:e11916. doi:10.1371/ journal.pone. 0011916

Mizrahi D, Kitahara MV, Barbosa AC, Flores AA (2016) Possible interference competition involving established fish and a sun coral incursion. Mar Biodivers. doi:10.1007/s12526-016-0477-2

Montano S, Galli P, Hoeksema BW (2017a) First record from the Atlantic: a Zanclea-scleractinian association at St. Eustatius, Dutch Caribbean. Mar Biodivers 47 (this issue). doi:10.1007/ s12526-015-0432-7

Montano S, Maggioni D, Galli P, Hoeksema BW (2017b) A cryptic species in the Pteroclava krempfi species complex (Hydrozoa, Cladocorynidae) revealed in the Caribbean. Mar Biodivers 47 (this issue). doi:10.1007/s12526-016-0555-5

Nagelkerken I, Kleijnen S, Klop T, Van den Brand RACJ, De La Moriniere EC, Van der Velde G (2001) Dependence of Caribbean reef fishes on mangroves and seagrass beds as nursery habitats: a comparison of fish faunas between bays with and without mangroves/seagrass beds. Mar Ecol Prog Ser 214:225-235. doi: 10.3354/meps214225

Netchy K, Hallock P, Lunz KS, Daly KL (2016) Epibenthic mobile invertebrate diversity organized by coral habitat in Florida. Mar Biodivers 46:451-463. doi:10.1007/s12526-015-0388-7

Nunes FL, Norris RD, Knowlton N (2011) Long distance dispersal and connectivity in amphi-Atlantic corals at regional and basin scales. PLoS One 6:e22298. doi:10.1371/journal.pone.0022298

Nuttall MF, Johnston MA, Eckert RJ, Embesi JA, Hickerson EL, Schmahl GP (2014) Lionfish (Pterois volitans [Linnaeus, 1758] and $P$. miles [Bennett, 1828]) records within mesophotic depth ranges on natural banks in the Northwestern Gulf of Mexico. BioInvasions Rec 3:111-115 
Obura DO (2016) An Indian Ocean centre of origin revisited: Palaeogene and Neogene influences defining a biogeographic realm. J Biogeogr 43:229-242. doi:10.1111/jbi.12656

Pawson DL, Pawson DJ (2013) Bathyal sea urchins of the Bahamas, with notes on covering behavior in deep sea echinoids (Echinodermata: Echinoidea). Deep Sea Res II 92:207-213. doi:10.1016/j.dsr2.2013. 01.023

Petuch EJ (2013) Biogeography and biodiversity of western Atlantic mollusks. CRC Press, Boca Raton

Pinto TK, Benevides LJ, Sampaio CLS (2016) Cyphoma macumba Petuch 1979 (Gastropoda: Ovulidae): a versatile predator of the Brazilian Octocorallia. Mar Biodivers. doi: 10.1007/s12526-016-0470-9

Porto-Hannes I, Lasker HR (2013) Isolation and characterization of 7 microsatellite loci in the Caribbean gorgonian Antillogorgia elisabethae. Mar Biodivers 43:273-277. doi: 10.1007/s12526-013-0154-7

Potkamp G, Vermeij MJA, Hoeksema BW (2017) Host-dependent variation in density of corallivorous snails (Coralliophila spp.) at Curaçao, southern Caribbean. Mar Biodivers 47 (this issue). doi: 10.1007/s12526-016-0596-9

Randall JE (1963) Three new species and six new records of small serranoid fishes from Curaçao and Puerto Rico. Stud Fauna Curaçao Caribb Is 19:77-110

Reijnen BT, Hoeksema BW, Gittenberger E (2010) Host specificity and phylogenetic relationships among Atlantic Ovulidae (Mollusca: Gastropoda). Contrib Zool 79:69-78

Reimer JD, Wee HB, Put A Jr, Hoeksema BW (2015) Zoantharia (Cnidaria: Anthozoa: Hexacorallia) of the South China Sea and Gulf of Thailand: a species list based on past reports and new photographic records. Raffles Bull Zool 63:334-356

Reuscher MG, Shirley TC (2014) Diversity, distribution, and zoogeography of benthic polychaetes in the Gulf of Mexico. Mar Biodivers 44: 519-532. doi:10.1007/s12526-014-0222-7

RLG (2009) Coral reefs in the Netherlands. An advice on the support of nature policy on the BES islands. Publication RLG 09/04. Ministry of Agriculture, Nature and Food Quality, The Hague

Roberts CM, McClean CJ, Veron JEN, Hawkins JP, Allen GR, McAllister DE et al (2002) Marine biodiversity hotspots and conservation priorities for tropical reefs. Science 295:1280-1284. doi: 10.1126/science. 1067728

Robertson DR, Cramer KL (2014) Defining and dividing the Greater Caribbean: insights from the biogeography of shorefishes. PLoS One 9(7):e102918. doi:10.1371/journal.pone.0102918

Rocha LA, Rocha CR, Robertson DR, Bowen BW (2008) Comparative phylogeography of Atlantic reef fishes indicates both origin and accumulation of diversity in the Caribbean. BMC Evol Biol 8:157. doi:10.1186/1471-2148-8-157

Rocha LA, Aleixo A, Allen G, Almeda F, Baldwin CC, Barclay MV et al (2014) Specimen collection: an essential tool. Science 344:814-815. doi:10.1126/science.344.6186.814

Rocha LA, Rocha CR, Baldwin CC, Weigt LA, McField M (2015) Invasive lionfish preying on critically endangered reef fish. Coral Reefs 34:803-806. doi:10.1007/s00338-015-1293-z

Roos PJ (1964) The distribution of reef corals in Curaço. Stud Fauna Curaçao Caribb Is 20:1-51

Roos PJ (1971) The shallow-water stony corals of the Netherlands Antilles. Stud Fauna Curaçao Caribb Is 37:1-108

Ruiz Allais JP, Amaro ME, McFadden CS, Halász A, Benayahu Y (2014) The first incidence of an alien soft coral of the family Xeniidae in the Caribbean, an invasion in eastern Venezuelan coral communities. Coral Reefs 33:287. doi:10.1007/s00338-013-1122-1

Ruiz-Abierno A, Armenteros M (2017) Coral reef habitats strongly influence the diversity of macro- and meiobenthos in the Caribbean. Mar Biodivers 47 (this issue). doi:10.1007/s12526-016-0553-7
Sampey A, Marsh LM (2015) Kimberley marine biota. Historical data: echinoderms. Rec West Aust Mus Suppl 84:207-246. doi:10.18195/ issn.0313-122x.84.2015.207-246

Santodomingo N, Reyes J, Flórez P, Chacón-Gómez IC, Van Ofwegen LP, Hoeksema BW (2013) Diversity and distribution of azooxanthellate corals in the Colombian Caribbean. Mar Biodivers 43:7-22. doi:10.1007/s12526-012-0131-6

Santos MEA, Kitahara MV, Lindner A, Reimer JD (2016) Overview of the order Zoantharia (Cnidaria: Anthozoa) in Brazil. Mar Biodivers 46:547-559. doi:10.1007/s12526-015-0396-7

Snijders N, Fransen CHJM (2010) Pseudopontonides plumosus sp. nov., a new cnidarian-associated pontoniine shrimp (Crustacea, Decapoda, Palaemonidae) from Curaçao. Zootaxa 2372:7-14

Soares MO, Davis M, De Paiva CC, Carneiro PBM (2016a) Mesophotic ecosystems: coral and fish assemblages in a tropical marginal reef (northeastern Brazil). Mar Biodivers. doi: 10.1007/s12526-016-0615-x

Soares MO, Davis M, Carneiro PBM (2016b) Northward range expansion of the invasive coral (Tubastraea tagusensis) in the southwestern Atlantic. Mar Biodivers. doi:10.1007/s12526-016-0623-x

Spalding MD, Ravilious C, Green EP (2001) World atlas of coral reefs. The University of California Press, Berkeley

Spalding MD, Fox HE, Allen GR, Davidson N, Ferdaña ZA, Finlayson MA et al (2007) Marine ecoregions of the world: a bioregionalization of coastal and shelf areas. Bioscience 57:573583. doi:10.1641/B570707

Stampar SN, González-Muñoz R, Morandini AC (2017) Botruanthus mexicanus (Cnidaria: Ceriantharia), a new species of tubedwelling anemone from the Gulf of Mexico. Mar Biodivers 47 (this issue). doi:10.1007/s12526-016-0521-2

Stegenga H, Vroman M (1987) Notes on some Ceramiaceae (Rhodophyta) from Curaçao, especially those from the exposed northeast coast. Blumea 32:397-426

Stock JH (1973) Copepoda of the family Lamippidae from the western Atlantic and the Caribbean. Stud Fauna Curaçao Caribb Is 43:22-41

Stock JH (1989) Pycnogonida collected in interstitia of coral sand and rubble in the Netherlands Antilles. Amsterdam Expeditions to the West Indian Islands, Report 58. Bijdr Dierk 59:87-96

Stock JH, Humes AG, Gooding RU (1963) Copepoda associated with West Indian Invertebrates - II Cancerillidae, Micropontiidae (Siphonostoma). Stud Fauna Curaçao Caribb Is 15:1-23

Ten Hove HA (1970) Serpulinae (Polychaeta) from the Caribbean: I The genus Spirobranchus. Stud Fauna Curaçao Caribb Is 32:1-57

Thomas JD, Klebba KN (2007) New species and host associations of commensal leucothoid amphipods from coral reefs in Florida and Belize (Crustacea: Amphipoda). Zootaxa 1494:1-44

Tornabene L, Robertson DR, Baldwin CC (2016a) Varicus lacerta, a new species of goby (Teleostei, Gobiidae, Gobiosomatini, Nes subgroup) from a mesophotic reef in the southern Caribbean. ZooKeys 596: 143-156. doi:10.3897/zookeys.596.8217

Tornabene L, Van Tassell JL, Gilmore RG, Robertson DR, Young F, Baldwin CC (2016b) Molecular phylogeny, analysis of character evolution, and submersible collections enable a new classification of a diverse group of gobies (Teleostei: Gobiidae: Nes subgroup), including nine new species and four new genera. Zool J Linnean Soc 177:764-812. doi:10.1111/zoj.12394

Tornabene L, Van Tassell JL, Robertson DR, Baldwin CC (2016c) Repeated invasions into the twilight zone: evolutionary origins of a novel assemblage of fishes from deep Caribbean reefs. Mol Ecol 25:3662-3682. doi:10.1111/mec.13704

Van den Hoek C (1978) Marine algae from the coral reef of Curaçao, Netherlands Antilles. I. Three new and one rarely observed species from the steep fore-reef slope. Aquat Bot 5:47-61. doi:10.1016/ 0304-3770(78)90046-3

Van der Land J (1968) Florarctus antillensis, a new tardigrade from the coral sand of Curaçao. Stud Fauna Curaçao Caribb Is 26:140-146 
Van der Land J (1977) The Saba Bank, a large atoll in the northeastern Caribbean. FAO Fish Rep 200:469-481

Van der Loos LM, Prud'homme van Reine WF (2017) First Atlantic record of the green alga Parvocaulis exiguus from St. Eustatius, Dutch Caribbean. Mar Biodivers 47 (this issue). doi:10.1007/ s12526-016-0494-1

Van der Loos LM, Prud'homme van Reine WF, Stokvis FR, Speksnijder AGCL, Hoeksema BW (2017) Beta diversity of macroalgal communities around St. Eustatius, Dutch Caribbean. Mar Biodivers 47 (this issue). doi: 10.1007/s12526-016-0608-9

Van der Meij SET (2014) Host species, range extensions, and an observation of the mating system of Atlantic shallow-water gall crabs (Decapoda: Cryptochiridae). Bull Mar Sci 90:1001-1010. doi:10. 5343/bms.2014.1017

Van der Meij SET, Van Tienderen KM, Hoeksema BW (2015) A mesophotic record of the gall crab Opecarcinus hypostegus from a Curaçaoan reef. Bull Mar Sci 91:205-206. doi:10. 5343/bms.2014.1072

Van Duyl FC (1985) Atlas of the living reefs of Curaçao and Bonaire (Netherlands Antilles). Publ Found Sci Res Surinam Neth Antilles 117:1-38

Van Ofwegen LP (2005) A new genus of nephtheid soft corals (Octocorallia: Alcyonacea: Nephtheidae) from the Indo-Pacific. Zool Meded 79(4):1-236

Van Ofwegen LP, Haddad MA (2011) A probably invasive new genus and new species of soft coral (Octocorallia: Alcyonacea: Clavulariidae) from Brazil. Zootaxa 3107:38-46

Van Soest RWM (1980) Marine sponges from Curaçao and other Caribbean localities. Part II. Haplosclerida. Stud Fauna Curaçao Caribb Is 62:1-173

Van Soest RWM, Meesters EH, Becking LE (2014) Deep-water sponges (Porifera) from Bonaire and Klein Curaçao, Southern Caribbean. Zootaxa 3878:401-443. doi:10.11646/zootaxa.3878.5.1

Van Tassell JL, Tornabene L, Collin PL (2012) Review of the western Atlantic species of Bollmannia (Teleostei: Gobiidae: Gobiosomatini) with the description of a new allied genus and species. Aqua Int J Ichthyol 18:61-94

Van Tienderen KM, Van der Meij SET (2016) Occurrence patterns of coral-dwelling gall crabs (Cryptochiridae) over depth intervals in the Caribbean. PeerJ 4:e1794. doi:10.7717/peerj.1794
Van Tussenbroek BI, Van Katwijk MM, Bouma TJ, Van der Heide T, Govers LL, Leuven RSEW (2016) Non-native seagrass Halophila stipulacea forms dense mats under eutrophic conditions in the Caribbean. J Sea Res 115:1-5. doi:10.1016/j.seares.2016.05.005

Vermeij MJA, Diekmann OE, Bak RPM (2003) A new species of scleractinian coral (Cnidaria, Anthozoa), Madracis carmabi n. sp. from the Caribbean. Bull Mar Sci 73:679-684

Veron JEN (1995) Corals in space and time: the biogeography and evolution of the Scleractinia. Cornell University Press, Ithaca

Vonk R (1988) Psammomelita uncinata n.g., n.sp. (Crustacea, Amphipoda, Melitidae) from infralittoral sand interstices on Curaçao. Stygologia 4:166-176

Vonk R (1989) Nuuanu curvata n. sp. and Melita leiotelson n. sp.(Crustacea, Amphipoda) from beach interstitia on Curaçao. In: Van der Steen LJ (ed) Studies in honour of Dr. Pieter Wagenaar Hummelinck. Uitgaven Natuurwetenschappelijke Studiekring voor Suriname en de Nederlandse Antillen, Amsterdam, pp 185-198

Vonk R (1990) Thalassostygius exiguus n.g., n.sp., a new marine interstitial melitid (Crustacea, Amphipoda) from Curaçao and Klein Bonaire (Netherlands Antilles). Stygologia 5:43-48

Vonk R, Lau YW (2017) Microcharon quilli, a new asellote isopod crustacean from interstitial spaces in shallow coralline sands off St. Eustatius, Caribbean Netherlands. Mar Biodivers 47 (this issue). doi:10.1007/s12526-016-0587-x

Vroman M (1967) A new species of Stichothamnion (Rhodophyta) from the West Indies. Acta Bot Neerl 15:557-561

Westinga EPHC, Hoetjes PC (1981) The intrasponge fauna of Spheciospongia vesparia (Porifera, Demospongiae) at Curaçao and Bonaire. Mar Biol 62:139-150. doi:10.1007/BF00388176

Wilkinson C, Souter D (2008) Status of Caribbean coral reefs after bleaching and hurricanes in 2005. Global Coral Reef Monitoring Network and Reef and Rainforest Research Centre, Townsville

Willette DA, Chalifour J, Debrot AOD, Engel MS, Miller J, Oxenford HA, Short FT, Steiner SCC, Védie F (2014) Continued expansion of the trans-Atlantic invasive marine angiosperm Halophila stipulacea in the Eastern Caribbean. Aquat Bot 112:98-102. doi:10.1016/j. aquabot.2013.10.001

Wolf AT, Nugues MM, Wild C (2014) Distribution, food preference, and trophic position of the corallivorous fireworm Hermodice carunculata in a Caribbean coral reef. Coral Reefs 33:1153-1163. doi:10.1007/s00338-014-1184-8 